Hypothesis

\title{
The Effect of Safety Management and Sustainable Activities on Sustainable Performance: Focusing on Suppliers
}

\author{
DonHee Lee \\ Department of Business Administration, Inha University, Incheon 402751, Korea; dhlee04@inha.ac.kr
}

Received: 21 November 2018; Accepted: 13 December 2018; Published: 15 December 2018

\begin{abstract}
This research empirically examines the effect of safety management and sustainable activities on sustainable performance of work safety and workplace environments. The proposed model with developed hypotheses were tested using the data collected from 189 respondents in Korean firms across various industries. The research findings indicate that planning and control systems affect activities of participation and monitoring in supply chain management (SCM) processes, which in turn positively affect sustainable performance. The results of the study present practical implications regarding the relationships among planning and control, participation and monitoring activities, and the performance of work safety and workplace environments. The study also provides new insights and implications regarding firms' investment strategies for safety management to facilitate sustainable work environments. Activities of participation and monitoring within SCM are especially critical for sustainable safety management and efficient operations.
\end{abstract}

Keywords: safety management; planning and control system; participation and monitoring; sustainable performance; sustainability

\section{Introduction}

Recently, climate change has received significant attention. Businesses, for example, have begun to address the possibility of climate change-induced disruptions of their supply chains, which could disrupt connections with suppliers and customers [1]. According to the U.S. National Centers for Environmental Information, the cumulative damage of extreme weather and climate events in 2017 was \$306.2 billion [2]. In particular, the natural disasters of 2017 and 2018 (e.g., record-breaking hot weather, new winter lows of Arctic sea ice, longer and much more widespread wildfires, and hurricanes) indicate that climate change is becoming more intense. As a result, enterprises are expected to invest more technical resources toward disaster prevention and mitigation as well as climate resilience, rather than just recovery [2]. The BSR (Business for Social Responsibility) report "The Future of Sustainable Business" predicted that no company will be unaffected by climate change [3]. Thus, to protect their businesses, firms should invest in advanced technologies, new business models, and support policies that can drive critical climate-related challenges $[1,4,5]$.

Sustainability has thus become a real challenge for society and businesses, from economic, social, environmental, and political perspectives [6]. Most organizations strive for sustainability internally by providing workplace conditions that are conducive to employee safety and health. Therefore, developing a workplace safety culture has become a competitive factor for sustainable companies [7,8]. While protecting employee safety and health has been a requirement since the 1970s, the UN Brundtland Commission report of 1987 announced that sustainability would emerge as a major issue [6]. Enterprises need to deal with risk and hazard management in the workplace to protect their employees' health and safety. Unfortunately, however, safety breaches remain common within the 
workplace, despite the implementation of rules and certification systems, with examples shown in references [9-11]. Safety in the workplace affects productivity and performance [12,13], ultimately affecting sustainable management activities.

As businesses become increasingly globalized, supply chains may extend into new regions, increasing uncertainty and risk. In particular, risk management on supply chains should include strategies for preventing and reducing risk in the uncertainty business environment [14]. Consequently, supply chain management (SCM) must consider health and safety issues across much wider areas [1,4]. It follows, then, that the sustainability of a business depends on safe and healthy workplaces across the entire supply chain, from suppliers and manufacturing to delivery of the product and customer services [6]. In particular, cooperation among partner firms with related activities in the supply chain is important. When this is the case, a company should holistically manage sustainability issues that arise in product supply or recovery. To ensure the sustainability of the entire supply chain, then, related firms must work together to build safe working environments. To assist those in the supply chain that are working towards achieving overall sustainability, the impact of the company's activities on employee safety, health, and the environment should be assessed. Strategic measures to improve the company's sustainability can then be formulated.

While firms strive to provide workers with safe and healthy workplaces, such efforts may not always be successful [15]. Businesses need to encourage, control, and participate in sustainable activities, particularly when core business activities have spread to various industries because of the extended supply chain [1]. In such situations, using planning and control factors can allow firms to more effectively monitor sustainable activities. Yet, there is a paucity of empirical research on the planning and control system for sustainable businesses, as well as on participation and monitoring activities to boost firm performance in the areas of safety and the environment. Therefore, this study focuses on strategies for promoting sustainable activities within SCM.

This study attempts to answer the following two research questions: (1) Does a firm's planning and control system impact on the participation and monitoring of sustainable activities in SCM? (2) Do the participation and monitoring activities for sustainable business have an impact on performances for work safety and the environment? A research model is proposed to answer these questions. The result of the study is expected to contribute to both theory and practice on sustainable SCM. Considering the study results presented based on previous studies, this research contributes to the literature by examining the proposed research model with developed hypotheses on sustainable SCM. Thus, the results of this research can be applied to safety management, sustainable activity and performance.

The rest of the paper is organized as follows: Section 2 reviews relevant literature; Section 3 proposes a research model with developed hypotheses; Section 4 presents research methodology; in Section 5, the results of analysis are reported; and Section 6 concludes the study with the discussion of results, implications and limitations of the study, and future research needs.

\section{Theoretical Background}

The UN Brundtland Commission [16] (p. 8) reported sustainable development as "development that meets the needs of the present without compromising the ability of future generations to meet their own needs". The report went on to suggest that positive integration of economic growth with social factors and stability creates sustainable development. The Rio Earth Summit of 1992 defined sustainability as "environmentally sound and sustainable development". The concept was further refined within ISO 14001 and ISO 26000, which emphasized social responsibility as requiring sustainability in the resources and environments of individuals, firms, communities, and stakeholders [1,17].

Shrivastava [18] (p. 955) defined sustainability as "the potential for reducing long-term risk associated with resource depletion, fluctuations in energy costs, product liabilities, and pollution and waste management". Góncz et al. [19] (p. 4) defined sustainability as "equal weightings for economic stability, ecological compatibility and social equilibrium." Summarizing these perspectives, 
sustainability is a comprehensive concept that emphasizes effective management of the environment in short- and long-term horizons to ensure that resources and social provisions will meet the needs of future generations [1]. Most definitions of sustainability encompass environmental and economic concerns, as well as the intersection of social and environmental issues.

Elkington [20] suggested that corporate sustainability can be achieved by pursuing economic profit, environmental protection, and ethics as the triple bottom line (TBL) of sustainability management to evaluate a firm's sustainability. Carter and Easton [21] used TBL to help suppliers improve sustainability in various activities, such as reducing costs for transportation and packaging, and designing systems for recycling and reuse. To ensure sustainability, firms should properly manage the entire process of transportation, use, production, post-sales recovery, and disposal of raw materials. In addition, a sustainable and safe working environment is required through collaboration with vendors in all processes of product manufacturing and service delivery within SCM.

SCM must control risk in uncertain supply chain environments. Previous studies have emphasized the need for risk management in SCM, the absence of which can lead to the inability to meet customer demand. SCM risk can arise from natural disasters, extreme weather [22], and poor environmental conditions $[23,24]$. SCM involves managing a complex network of various entities and structures, including such stakeholders as suppliers, partner firms, customers, government agencies, communities, and the society at large. Consequently, SCM needs to deal with ethical issues, cultural differences, societal problems, and environmental concerns. SCM becomes even more challenging when many uncertainties emerge, such as trade issues among the countries involved in the global supply chain, severe weather risks, and the velocity of demand changes $[1,5,21,23,24]$. As complexity of the supply chain and the number of partners involved can create confusion [14], Hallikas et al. [25] emphasized that the difficulty of managing risk in SCM involves demand, distribution, financial requirement, resources, and flexibility.

Carter and Rogers [26] (p. 368) defined sustainability in SCM as "the strategic, transparent integration and achievement of an organization's social, environmental, and economic goals in the systemic coordination of key interorganizational business processes for improving the long-term economic performance of the individual company and its supply chains".

Sustainable management in SCM involves a series of steps that lead to improved economic performance in the long term. Therefore, sustainable management should involve all stakeholders, consumers, and governments and not just focus on profit creation. Reiner [27] emphasized the importance of sustainable SCM and suggested that companies should actively follow environmental laws and regulations and fulfill social responsibilities to maintain sustainability. Thus, sustainability strategy should continuously guide business activities and involve close cooperation among partner firms. This ensures competitiveness, enhances corporate image, and builds trust in the economic ecosystem. Since the activities of companies directly or indirectly affect the economy, society, and environment, it is necessary to involve stakeholders such as related suppliers or venders, consumers, and communities in voluntary participation and monitoring activities.

\subsection{Preventive Planning and Control System}

Safety management is recognized as having an important role in protecting workers and reducing losses $[13,28]$. It reflects an organization's commitment to the well-being of workers and is an important building block of a safety culture, where employees also recognize the importance of safety $[28,29]$. A safety culture comprises a firm's philosophy and management practices aimed at reducing unsafe behavior, and it positively affects employee attitudes and behavior towards the reduction of risk [28,29]. Therefore, organizations should understand the importance of the recognition, understanding, motivation, and dedication of its members in building a safe work culture. It should be noted that only companies that understand the basic attitudes and perceptions of their employees would be able to create a truly safe workplace environment [28]. 
Safety management has evolved over time towards a preventive perspective $[29,30]$. In the past, safety management focused on solving problems based on outcomes of past issues, using the follow-up approach. However, with more awareness and understanding of accidents, a safety culture can evolve and be influenced by organizational characteristics (e.g., culture and climate). A safety perspective must change and adapt in order to influence the members of an organization [29]. This means that organizations need to find ways to build a safe workplace by cultivating the proper organizational culture or climate $[30,31]$. An important way to achieve this is to engage the efforts of upper management. Flin et al. [32] suggested that upper management has an essential role in building a safety culture. In addition to direct supervision, an effective management approach should also include other features (e.g., organizational policies, systems and procedures, leadership style, and commitment to safety) to encourage a safe workplace.

Sustainable organizations need to manage risk in an integrated way to reduce accidents and improve business productivity and performance $[33,34]$. However, very few studies have examined ways to create an integrated health and safety culture to reduce risk [35]. Labodová [36] suggested that organizational safety management should be based on a proactive system to control risks and prevent accidents. Moreover, to ensure that these activities are effective, both management and staff should actively participate in them [30,37].

To ensure sustainable business occurs, organizations should continuously monitor risk, engage in planning and proactive prevention, and thereby minimize accidents and losses [30,31]. In addition, internal and external controls should be implemented through cooperation with suppliers and vendors. Continuous improvement is possible through a regular review of activities performed in the workplace [30]. Accidents that do occur should be analyzed to determine their root causes and prevent future occurrences. Thus, sustainable businesses should exercise planning and control systems for the prevention and management of accidents.

In this study, we consider planning and control systems as prerequisites for building a safety culture. The planning and control system aspect of this study includes precautionary guidance for controlling hazards. This study employed measurement items of planning and control factors of sustainability based on Fernández-Muñiz et al. [30].

\subsection{Participation and Monitoring Activities}

The sustainable participation of a firm can change based on consumer needs. In addition, a company's sustainability hinges on its collaboration with suppliers throughout the global supply chain, who must be transparent about and responsible for environmental performance and even human rights issues [1].

Firms must adequately manage risks and hazards to protect the safety of workers in the workplace [9-11]. Risk should be systematically assessed and if hazards cannot be rectified immediately, plans should be developed and follow-up actions taken $[7,8,15]$. These efforts can be improved through continuous participation of internal and external stakeholders and through monitoring activities. For example, a major supplier may receive environmental requirements in writing, needing immediate action, or an audit of environmental compliance. In other words, sustainable participation activities not only ensure a safe workplace, but they also are in compliance with safety requirements and address systemic weaknesses through employee participation. Therefore, an organizational culture should be developed that supports a safe workplace.

An organizational culture is characterized by the common values and norms shared by individual members [38,39]. However, culture is only one of many factors influencing behavior [40]. A safety culture involves the healthy, safe, risky, and hazardous aspects of a particular workplace culture $[15,41]$. In the past, a workplace safety-related culture was only associated with accidents and safe or unsafe behaviors [8]. Today, however, it includes factors that measure the entire state of a company's safety culture $[41,42]$. This evolution is all part of the ongoing effort to create safe organizational cultures by eliminating risks and hazards in the workplace. 
In addition to participation activities, the organization should also engage in continuous monitoring activities. For example, suppose an automobile parts supply system is concerned with products that meet the design and manufacturing regulations specified by a buyer. It is possible for a group of firms to supply raw materials, components, or parts (e.g., plating, mold, press, and assembly) to automobile manufacturers (module production and assembly parts companies). Because of the characteristics of automobile parts, the first supplier's product becomes a product for the higher-level buyer. Parts companies combine single products in ways that will meet the needs of further higher-level buyers, and then module and component manufacturers execute processes that will allow them to supply components to meet automobile manufacturers' demands. In the process, suppliers and buyers will participate in a web of sustainable activities and work together to build a sustainable environment through monitoring.

Sustainable monitoring activities can help improve a sustainable business environment. Monitoring of internal activities might include the following: employee safety procedures in the workplace; industrial accidents; the number of accident claims; and the use of energy, water, and waste. In contrast, external monitoring activities may include the following: providing environmental protection requirements to major suppliers and implementing them; monitoring suppliers' compliance with regulations; implementing health and safety improvement goals; and monitoring suppliers' employees' health and safety. Sustainable activities of suppliers are also important because end-product makers become a source of competitiveness. To maximize the value of products and services within a supply chain to enhance the ultimate value for customers, a company should ensure corporate competitiveness by cooperating with other partner firms to secure its position within the business ecosystem and to build trust with other ecosystem members [1]. Thus, to achieve a sustainable business firms should continuously implement sustainable activities.

In this study, as discussed above, a company's sustainability activities are divided into participation and monitoring activities. In this view, a safe working environment is a prerequisite for sustainability and should be predicated on the voluntary participation of members of the organization. Therefore, in this study, participation activities are the activities of the firm, its members, and partners to reduce and remove risks and hazards in order to build a safe and sustainable workplace environment.

All the processes involved in SCM, from purchasing raw materials to delivering products to the final consumer to recycling, reusing, and disposing of products can eliminate or minimize environmental harm. These activities require participation from suppliers as well as consumers. Implementation methods can be improved through repetition and practice; therefore, all activities should be monitored and analyzed to extract information and knowledge, which can be used to establish strategic targets of sustainable development.

In this study, monitoring activities are considered to be those internal and external activities that contribute to the building of a safe and sustainable workplace environment. Measurement items for sustainability participation and monitoring were adopted from the Global Manufacturing Research Group's (GMRG: Kansas, USA) 5.0 survey questionnaire, which was conducted by a multinational community of researchers dedicated to the study of global manufacturing practices.

\subsection{Sustainable Performance: Work Safety and Environmental Performance}

Previous studies on sustainable performance (e.g., reference [43]) proposed that sustainable performance assessment of SCM should include social, economic, and environmental dimensions of SCM. Also, firms should include these assessments as outputs when participating in environmental regulation as part of corporate social responsibility (CSR) activities [1,27]. However, in this study, sustainable performance is divided into work safety and environmental performance in the workplace, as these dimensions can be ensured through member participation in sustainability and internal and external monitoring based on planning and control activities.

As discussed above, building a safe workplace is a prerequisite for a sustainable business, and performance can be improved through the careful documentation and analysis of accidents [30]. 
This indirectly implies that safety in the workplace plays a positive role in improving organizational performance [44]. Thus, organizations can improve performance by strengthening systems for planning and controlling safety management, addressing any gaps in current safety management practices, and by a comparative study with other firms. In this study, sustainable performance is defined as the improvement in work safety and environmental performance that results from cooperation between suppliers and buyers in SCM.

Safety-related performance in the workplace can reduce accidents by increasing the likelihood that work will be performed in compliance with safety regulations [13]. The commonality between an organization's safety culture, climate, and safety management system is that all these dimensions have variables that can indicate whether employees are working in a safe environment. These variables, such as the reduction in accidents and disaster rates, the health of employees, and the number of claims of industrial accidents, are studied as important performance items $[45,46]$. Therefore, in this study, work safety performance is viewed as something that could be achieved through the participation of employees, and its measurement items are based on the GMRG 5.0 survey questionnaire.

Sustainable activities are the ultimate goal of building a sustainable ecosystem with minimal environmental impact [1]. Thus, companies should strive to comply with legal and environmental requirements related to their business activities, including both external and internal factors. In particular, SCM can improve environmental performance through a reduction in harmful environmental factors (pollution emission criteria, etc.) and through the development of a sustainable environment with suppliers [47]. Previous studies related to environmental performance showed reduced labor costs at higher productivity levels, lower processing costs, improved product quality, and reduced absenteeism by improved working conditions [43].

In this study, environmental performance is defined as the degree of environmental performance achievable through the participation of supply chain employees. The measurement items of environmental performance are adopted from the GMRG 5.0 survey questionnaire.

\section{Research Model and Hypotheses}

We examine in this study the effects of planning and control system on health, safety, and environmental performance through participation and monitoring activities for sustainable activities in SCM. This study, based on previous research, posits that the safety management prerequisite activities for the firm's sustainable business within SCM have a positive impact on sustainable activities, and then sustainable activities improve work safety and environmental performance in the workplace. The proposed research model is shown in Figure 1.

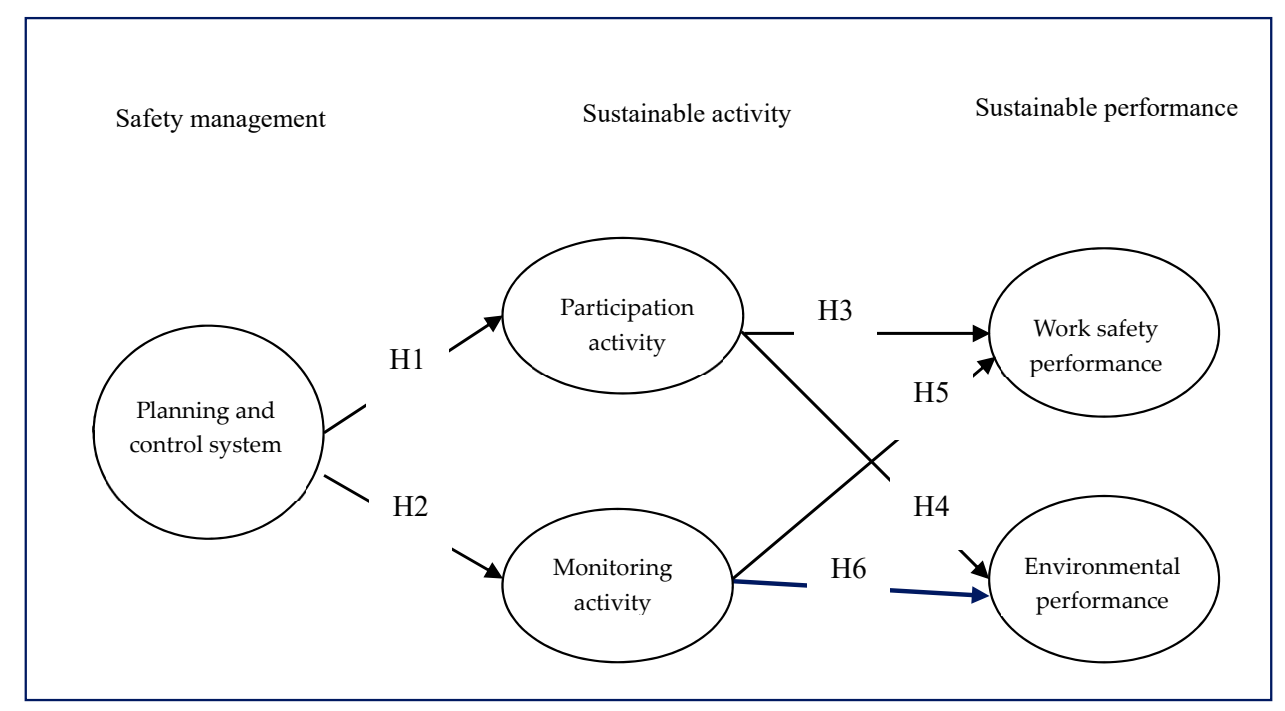

Figure 1. The proposed research model. 
A sustainable workplace should be provided to employees to secure a sustainable business. In other words, when a company provides a safe workplace, employees recognize this and become more productive in their work [48]. In addition, planning and control system can induce voluntary participation by organizational members, and activities to prevent or control safety problems can have a positive impact on monitoring.

Neal et al. [13] showed that an organizational climate that supports safety indirectly influences safety compliance and participation through the determinants of safety motivation. In other words, they suggested that a safe environment positively affects participation. Griffin and Neal [49] suggested that an organizational climate that supports safety affects the motivation and participation of organizational members. Thus, safety management prerequisites (planning and control) for a firm's sustainable business may affect its sustainable activities (participation and monitoring). The following hypotheses are proposed.

Hypothesis 1 (H1). The planning and control system for safety management has a positive effect on participation activities of employee.

Hypothesis 2 (H2). The planning and control system for safety management has a positive effect on monitoring activities of employee.

Employees who recognize safety in the workplace are reassured to carry out their assigned tasks [50]. Barling et al. [12] suggested that managers who perceived safety as more important showed more positive perceptions of safety in the work environment and were less likely to engage in unsafe behavior. This is because the safety climate is directly related to the participation of members $[13,33]$.

A company must provide its employees with a legally safe and healthy working environment depending on the type of business; every organization has its own unique health and safety management system according to the amount of risk involved in the work. However, no matter how well devised a system or policy may be, if it is not managed and monitored continuously, it may degrade over time. That is, only a planned and systematic approach to risk control management would ensure the longevity of safe and healthy workplaces. Thus, it follows that a safe workplace can be built more efficiently through participation and monitoring activities of members with support from management [12,48].

The control of accidents depends on whether the members are freely participating in activities and whether hazards can be reasonably minimized. For example, regular monitoring activities can assess whether safety management measures have been implemented properly. Monitoring activities may include regular meetings, worker feedback, and environmental monitoring of things such as air quality, suitable light, and noise testing. Thus, participation and monitoring activities by members can improve overall work safety as well as environmental performance.

In particular, companies should reduce social and environmental risk by adding these perspectives to existing SCM activities, thereby strengthening SCM capabilities at the same time $[1,4,51,52]$. Chhabara [53] suggested that a monitoring system should be strengthened to prevent social and environmental problems in SCM, and sustainable performance standards should be used to evaluate suppliers. Therefore, sustainable activities in SCM will have a significant positive effect on work safety and environmental performance. Thus, the following hypotheses are suggested.

Hypothesis 3 (H3). The participation activities of employees have a positive effect on work safety performance.

Hypothesis 4 (H4). The participation activities of employees have a positive effect on environmental performance.

Hypothesis 5 (H5). The monitoring activities of employees have a positive effect on work safety performance.

Hypothesis 6 (H6). The monitoring activities of employees have a positive effect on environmental performance. 


\section{Research Methodology}

\subsection{Data Collection}

Data was collected from first and second tier supplier firms through physical visits and online contacts of the staff of related SCM firms during 1 September to 30 October 2018 in South Korea. First and second tier supplier firms in this survey participated on a voluntary basis. A survey questionnaire was developed using the double translation protocol [54]. The measurement items for the planning and control system for safety management, participation and monitoring activity for sustainability, and work safety and environmental performance in SCM are shown in Table 1.

Table 1. Measurement items.

\begin{tabular}{|c|c|c|}
\hline Variables & Measurement Items & References \\
\hline $\begin{array}{l}\text { Planning and } \\
\text { control system }\end{array}$ & $\begin{array}{l}\text { PCS1: a prevention plan circulated among all workers } \\
\text { PCS2: firm systems to identify risk in all job positions } \\
\text { PCS3: standards of action or work procedures based on risk evaluation } \\
\text { PCS4: periodic checks of prevention plan execution and compliance } \\
\text { with regulations } \\
\text { PCS5: a system for ensuring that all accidents and incidents are } \\
\text { reported, investigated, analyzed, and recorded }\end{array}$ & $\begin{array}{l}\text { Fernández-Muñiz } \\
\text { et al. [30] }\end{array}$ \\
\hline $\begin{array}{l}\text { Participation } \\
\text { activity }\end{array}$ & $\begin{array}{l}\text { PAF1: control the impact of our production process on } \\
\text { occupational safety } \\
\text { PAF2: a systematic approach to setting occupational safety targets } \\
\text { PAF3: a systematic approach to achieving occupational safety targets } \\
\text { PAF4: a systematic approach to demonstrating that occupational safety } \\
\text { targets have been meet } \\
\text { PAF5: control the environmental impact of our products and processes } \\
\text { PAF6: a systematic approach to setting environmental targets } \\
\text { PAF7: a systematic approach to achieving environmental targets } \\
\text { PAF8: a systematic approach to demonstrating that environmental } \\
\quad \text { targets have been met }\end{array}$ & \\
\hline $\begin{array}{l}\text { Monitoring } \\
\text { activity }\end{array}$ & $\begin{array}{l}\text { MAF1: the occurrence of occupational-related accidents at our facilities } \\
\text { MAF2: occupational employee health and safety procedures at } \\
\text { our facilities } \\
\text { MAF3: the long-term health of our employees at our facilities } \\
\text { MAF4: energy usage in our facilities } \\
\text { MAF5: water usage in our facilities } \\
\text { MAF6: waste re-usage at our facilities }\end{array}$ & $\begin{array}{l}\text { GMRG } 5.0 \text { survey } \\
\text { questionnaire [55] }\end{array}$ \\
\hline $\begin{array}{l}\text { Work safety } \\
\text { performance }\end{array}$ & $\begin{array}{l}\text { HSP1: reduced the number of occupational-related accidents at } \\
\text { our facilities } \\
\text { HSP2: reduced the number of occupational-related injuries at } \\
\text { our facilities } \\
\text { HSP3: reduced occupational-related ill health at our facilities reduced } \\
\text { HSP4: reduced the number of occupational-related insurance claims at } \\
\text { our facilities }\end{array}$ & \\
\hline $\begin{array}{l}\text { Environmental } \\
\text { performance }\end{array}$ & $\begin{array}{l}\text { ENP1: reduced energy use in our facilities } \\
\text { ENP2: reduced water usage in our facilities } \\
\text { ENP3: reduced waste at our facilities } \\
\text { ENP4: reduced emissions at of our facilities }\end{array}$ & \\
\hline
\end{tabular}


Out of 500 questionnaires that were distributed to first and second tier supplier firms in South Korea, 194 (38.8\%) responses were received. Incomplete questionnaires or those with missing items were discarded. The final study sample consisted of 189 (37.8\%) valid returned questionnaires.

The descriptive sample characteristics of the firms and respondents are summarized in Table 2. The majority of business units are manufacturers of motor vehicles $(68.3 \%)$, metal industry $(15.3 \%)$, electronic and other electrical equipment, and petroleum refining and related industries (3.7\%). Of the respondents, $97.5 \%$ were male, and working experiences in current organization varied from less than 5 years $(30.2 \%)$ to more than 20 years $(7.9 \%)$.

Table 2. General characteristics of firms and respondents.

\begin{tabular}{|c|c|c|c|}
\hline \multicolumn{2}{|r|}{ Characteristics of Firms } & \multirow{2}{*}{$\begin{array}{c}\text { Frequency } \\
57\end{array}$} & \multirow{2}{*}{$\begin{array}{c}\text { Percent } \\
22.8\end{array}$} \\
\hline \multirow{4}{*}{ Established years } & Less than 10 years & & \\
\hline & More than 10 years-less than 20 years & 65 & 34.4 \\
\hline & More than 20 years-less than 30 years & 44 & 23.3 \\
\hline & More than 30 years & 23 & 12.2 \\
\hline \multirow{5}{*}{ Number of employees } & Less than 30 & 45 & 23.8 \\
\hline & More than 30 less than 50 & 50 & 26.5 \\
\hline & More than 50 less than 100 & 45 & 23.8 \\
\hline & More than 100 less than 200 & 29 & 15.3 \\
\hline & More than 200 & 20 & 10.6 \\
\hline \multirow{7}{*}{ Number of partners } & Less than 10 & 67 & 35.4 \\
\hline & More than 10 -less than 20 & 42 & 22.2 \\
\hline & More than 20 -less than 30 & 22 & 11.6 \\
\hline & More than 30-less than 40 & 9 & 4.8 \\
\hline & More than 40 -less than 50 & 6 & 3.2 \\
\hline & More than 50 & 39 & 20.6 \\
\hline & Missing & 4 & 2.1 \\
\hline \multirow{5}{*}{$\begin{array}{c}\text { Years of average business } \\
\text { with other firms (by } \\
\text { August 2018) }\end{array}$} & Less than 5 years & 52 & 27.5 \\
\hline & More than 5 years-less than 10 years & 71 & 37.6 \\
\hline & More than 10 years-less than 20 years & 44 & 23.3 \\
\hline & More than 20 years & 8 & 4.2 \\
\hline & Missing & 14 & 7.4 \\
\hline \multirow{9}{*}{ Business unit } & Electronic and other electrical equipment & 7 & 3.7 \\
\hline & Manufacture of motor vehicles & 129 & 68.3 \\
\hline & Petroleum refining and related industries & 7 & 3.7 \\
\hline & Metal industry & 29 & 15.3 \\
\hline & Construction industry & 1 & 0.5 \\
\hline & Wholesale and Retail & 6 & 3.2 \\
\hline & Telecommunication and Information Services & 6 & 3.2 \\
\hline & Food and kindred products & 1 & 0.5 \\
\hline & Distribution and logistics & 3 & 1.6 \\
\hline \multicolumn{2}{|c|}{ Characteristics of Respondents } & Frequency & Percent \\
\hline \multirow{2}{*}{ Gender } & Male & 185 & 97.5 \\
\hline & Female & 4 & 2.1 \\
\hline \multirow{5}{*}{ Position } & Staff & 27 & 14.3 \\
\hline & Team Leader & 64 & 33.9 \\
\hline & Manager & 31 & 16.4 \\
\hline & Director/Supervisor & 13 & 6.9 \\
\hline & Executive & 54 & 28.6 \\
\hline \multirow{5}{*}{ Working years } & Less than 5 & 57 & 30.2 \\
\hline & More than 5-less than 10 & 63 & 33.3 \\
\hline & More than 10 -less than 15 & 30 & 15.9 \\
\hline & More than 15-less than 20 & 24 & 12.7 \\
\hline & More than 20 & 15 & 7.9 \\
\hline & Total & 189 & 100.0 \\
\hline
\end{tabular}




\subsection{Variables}

The questionnaire utilized 5-point Likert scales to measure the constructs. The collected data was analyzed using SPSS 21.0 (New York, NY, USA) and the AMOS 21.0 (New York, NY, USA) programs. Structural equation modeling (SEM) by AMOS 21.0 was chosen because it provides graphic representations and all of the tools necessary to test the hypotheses for this study.

Reliability was tested based on Cronbach's alpha value (Table 3). All of the coefficients of reliability measures for the constructs exceeded the threshold value of 0.8 for exploratory constructs in basic research [56]. For the reliability test, Cronbach's alpha value for work safety performance was the highest (0.963) while environmental performance was the lowest (0.891). Thus, all of the Cronbach's alpha values were significant at $p<0.05$.

For the validity test, the principal component analysis (PCA) and the confirmatory factor analysis (CFA) were used to identify the most meaningful basis and to examine similarities and differences of the data based on Brown's [57] recommendation. Eigen values and percent of variance explained for each construct are shown, and the cumulative percentages of explained variance were 79.463 for the constructs in Table 3. The loading values of each factor ranged from 0.619 to 0.885 as shown in Table 3. However, PAF4 variable of participation activity, which had a less than 0.5 loading value, was removed from this study (see Table 1).

For the convergent and discriminant validity of theoretical constructs [57], a measurement model was used with five components of planning and control systems, participation and monitoring activity, and performance of safety and environment. The standardized factor loadings and $t$-values for measurement variables, and results of CFA are presented in Table 3. The values of standardized loading of all variables proposed by the study were greater than 0.6 and statistically significant at the 0.05 level.

Table 3. Results of PCA and CFA.

\begin{tabular}{|c|c|c|c|c|c|c|c|c|}
\hline \multirow[b]{2}{*}{ Constructs } & \multirow[b]{2}{*}{ Variables } & \multicolumn{3}{|c|}{ PCA } & \multicolumn{3}{|c|}{ CFA } & \multirow[b]{2}{*}{$\begin{array}{l}\text { Cronbach's } \\
\text { Alphas }\end{array}$} \\
\hline & & $\begin{array}{l}\text { Eigen } \\
\text { Value }\end{array}$ & $\begin{array}{l}\text { Percent of } \\
\text { Variance } \\
\text { Explained }\end{array}$ & $\begin{array}{l}\text { Factor } \\
\text { Loadings }\end{array}$ & $\begin{array}{l}\text { Standardized } \\
\text { Loading }\end{array}$ & $t$-Value & $p$-Value & \\
\hline \multirow{5}{*}{$\begin{array}{l}\text { Planning and } \\
\text { control system }\end{array}$} & PCS1 & \multirow{5}{*}{2.901} & \multirow{5}{*}{11.156} & 0.795 & 0.861 & 15.111 & 0.000 & \multirow{5}{*}{0.954} \\
\hline & PCS2 & & & 0.862 & 0.923 & 16.61 & 0.000 & \\
\hline & PCS3 & & & 0.885 & 0.958 & 17.744 & 0.000 & \\
\hline & PCS4 & & & 0.876 & 0.93 & 16.839 & 0.000 & \\
\hline & PCS5 & & & 0.794 & 0.822 & - & - & \\
\hline \multirow{7}{*}{$\begin{array}{l}\text { Participation } \\
\text { activity }\end{array}$} & PAF1 & \multirow{7}{*}{13.079} & \multirow{7}{*}{50.305} & 0.727 & 0.709 & 10.953 & 0.000 & \multirow{7}{*}{0.927} \\
\hline & PAF2 & & & 0.689 & 0.675 & 10.247 & 0.000 & \\
\hline & PAF3 & & & 0.678 & 0.696 & 10.67 & 0.000 & \\
\hline & PAF5 & & & 0.717 & 0.879 & 15.074 & 0.000 & \\
\hline & PAF6 & & & 0.734 & 0.838 & 13.999 & 0.000 & \\
\hline & PAF7 & & & 0.742 & 0.862 & 18.382 & 0.000 & \\
\hline & PAF8 & & & 0.76 & 0.841 & - & - & \\
\hline \multirow{6}{*}{$\begin{array}{l}\text { Monitoring } \\
\text { activity }\end{array}$} & MAF1 & \multirow{6}{*}{1.936} & \multirow{6}{*}{7.445} & 0.619 & 0.755 & 13.079 & 0.000 & \multirow{6}{*}{0.921} \\
\hline & MAF2 & & & 0.637 & 0.783 & 13.722 & 0.000 & \\
\hline & MAF3 & & & 0.741 & 0.778 & 10.824 & 0.000 & \\
\hline & MAF4 & & & 0.818 & 0.754 & 12.696 & 0.000 & \\
\hline & MAF5 & & & 0.798 & 0.859 & 16.162 & 0.000 & \\
\hline & MAF6 & & & 0.669 & 0.899 & - & - & \\
\hline \multirow{4}{*}{$\begin{array}{l}\text { Work safety } \\
\text { performance }\end{array}$} & HSP1 & \multirow{4}{*}{1.596} & \multirow{4}{*}{6.139} & 0.822 & 0.913 & 22.445 & 0.000 & \multirow{4}{*}{0.963} \\
\hline & HSP2 & & & 0.832 & 0.944 & 24.953 & 0.000 & \\
\hline & HSP3 & & & 0.817 & 0.935 & 24.14 & 0.000 & \\
\hline & HSP4 & & & 0.829 & 0.929 & - & - & \\
\hline \multirow{4}{*}{$\begin{array}{l}\text { Environmental } \\
\text { performance }\end{array}$} & ENP1 & \multirow{4}{*}{1.148} & \multirow{4}{*}{4.418} & 0.741 & 0.774 & 11.492 & 0.000 & \multirow{4}{*}{0.891} \\
\hline & ENP2 & & & 0.84 & 0.864 & 13.204 & 0.000 & \\
\hline & ENP3 & & & 0.848 & 0.884 & 13.565 & 0.000 & \\
\hline & ENP4 & & & 0.702 & 0.786 & - & - & \\
\hline
\end{tabular}


The results of goodness of fit test for the measurement model are summarized and shown in Table 4. Based on the recommended values for the goodness of fit tests, the values of CFI, SRMR, RMSEA, $\chi^{2}$, and the $p$-value were satisfactory, while the values of GFI and AGFI were not. Deepen [58] (p. 238) suggested that GFI is desired to be over 0.9 , however, "this must not automatically require the model to be rejected." In this model, the majority of fit indices showed good acceptance measures, but GFI and AGFI were below the required threshold.

Table 4. Results of fit indices for CFA.

\begin{tabular}{ccccccccc}
\hline Model & $\chi^{2}$ & d.f & $\chi^{2} /$ d.f & GFI & AGFI & CFI & SRMR & RMSEA \\
\hline Measurement model & 562.175 & 277 & 2.030 & 0.881 & 0.870 & 0.944 & 0.071 & 0.074 \\
Recommended values & & \multicolumn{1}{c}{$\leq 3.0$} & $\geq 0.9$ & $\geq 0.9$ & $\geq 0.9$ & $\leq 0.08$ & $\leq 0.08$ \\
\hline
\end{tabular}

Table 5 provides the square roots of average variance extracted (AVE) of latent variables, while the off-diagonal elements are correlations between latent variables. For adequate discriminant validity, the square root of AVE of any latent variable should be greater than the correlation between a particular latent variable and other latent variables [59]. The convergent validity of the measurement model is to be assessed by AVE and CR [60], and AVE above 0.7 would be considered very good and above 0.5 is acceptable [60].

Table 5. Correlation matrix and average variance extracted (AVE).

\begin{tabular}{|c|c|c|c|c|c|}
\hline Factor & $\begin{array}{l}\text { Planning and } \\
\text { Control System }\end{array}$ & $\begin{array}{l}\text { Participation } \\
\text { Activity }\end{array}$ & $\begin{array}{l}\text { Monitoring } \\
\text { Activity }\end{array}$ & $\begin{array}{l}\text { Work Safety } \\
\text { Performance }\end{array}$ & $\begin{array}{c}\text { Environmental } \\
\text { Performance }\end{array}$ \\
\hline $\begin{array}{l}\text { Planning and } \\
\text { control system }\end{array}$ & 0.881 & & & & \\
\hline $\begin{array}{l}\text { Participation } \\
\text { activity }\end{array}$ & $0.608^{* *}$ & 0.787 & & & \\
\hline $\begin{array}{l}\text { Monitoring } \\
\text { activity }\end{array}$ & $0.534^{* *}$ & $0.693 * *$ & 0.819 & & \\
\hline $\begin{array}{l}\text { Work safety } \\
\text { performance }\end{array}$ & $0.397^{* *}$ & $0.657^{* *}$ & $0.638^{* *}$ & 0.949 & \\
\hline $\begin{array}{l}\text { Environmental } \\
\text { performance }\end{array}$ & $0.429 * *$ & $0.449 * *$ & $0.540 * *$ & $0.640 * *$ & 0.851 \\
\hline CR & 0.946 & 0.919 & 0.924 & 00.974 & 0.913 \\
\hline AVE & 0.777 & 0.620 & 0.671 & 0.902 & 0.725 \\
\hline
\end{tabular}

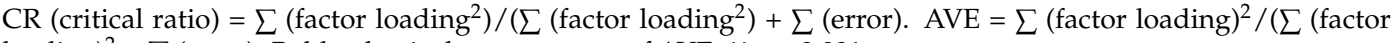
loading $)^{2}+\sum$ (error). Bold value is the square root of AVE. ${ }^{* *} p<0.001$.

As CR is considered to be a less biased estimate of reliability than Cronbach's alpha, the acceptable value of $C R$ is above 0.7. The values of AVE and CR for planning and control, participation and monitoring activity, and performance of work safety and environment were all greater than 0.6 and 0.7 , respectively. Thus, convergent validity met the threshold. The statistics shown in Table 5 satisfied the overall requirement as lending to discriminant validity and evidence to construct validity.

\section{Results and Discussion}

This section presents the results of hypotheses tests along with the standardized coefficient of each path in the model. As a result of the goodness of fit test, the proposed model had the values of GFI (0.886), AGFI (0.856), CFI (0.936), RMSEA (0.078), SRMR (0.077) that were good for fit and $\chi^{2} / \mathrm{d} . \mathrm{f}$ (2.156) and $p$-value (0.000) were significant. However, the value of GFI (0.886) and AGFI (0.856) did not satisfy the recommended values. 
Table 6 presents the result of the significance test for the research model as well as the summary of the hypotheses test. For $\mathrm{H} 1$ and H2, the standardized path coefficients between planning and control system and participation and monitoring activity were 0.639 and 0.525 , respectively, and statistically significant at the 0.001 level. Thus, $\mathrm{H} 1$ and H2 were supported. The results of this study are similar to those of previous studies e.g., [30,32]. Organizations that provide workers with a safe workplace through a well-designed planning and control system tend to encourage, control, and participate in sustainable activities for their employees $[13,28]$.

For $\mathrm{H} 3$ and $\mathrm{H} 4$, the standardized path coefficients between participation activity and work safety performance were 0.396 , and between participation activity and environmental performance were 0.227 and statistically significant at the 0.01 level, supporting H3 and H4. The results of this study are similar to those of previous studies e.g., references [7,8,33]. If an organization has an effective production process for occupational safety through participation activity to reduce possible risk in the workplace, it would provide employees with opportunities to induce voluntary participation. To control the environmental impact on SCM, the firm should develop sustainable role with suppliers through collaboration, such as a systematic and integrated approach to setting and achieving environmental goals in SCM activities.

For $\mathrm{H} 5$ and H6, the standardized path coefficients between monitoring activity and work safety performance were 0.446 , and between monitoring activity and environmental performance were 0.450 and statistically significant at the 0.01 level, supporting H5 and H6. The results of this study are similar to those of previous studies e.g., references [12,48,53]. Monitoring activity for improving safety and environmental performance can help prevent that risky and hazards can be reasonably minimized in work place or SCM processes with suppliers [4,51]. SCM processes through suppliers impact on the firm's capabilities, which allows internal and external activities to develop the best approach for reducing occupational-related accidents at facilities and environmental issues (e.g., energy, water, waste, and emissions of facilities).

Table 6. Results of significance test for paths of the model.

\begin{tabular}{|c|c|c|c|c|c|c|c|}
\hline \multicolumn{3}{|c|}{ Path } & \multirow{2}{*}{$\frac{\text { Path Coefficient }}{0.639}$} & \multirow{2}{*}{$\begin{array}{r}\text { S.E. } \\
0.059\end{array}$} & \multirow{2}{*}{$\begin{array}{c}\boldsymbol{t} \text {-Value } \\
8.919\end{array}$} & \multirow{2}{*}{$\begin{array}{l}p \text {-Value } \\
0.000^{* *}\end{array}$} & \multirow{2}{*}{$\begin{array}{c}\text { Hypothesis Test } \\
\text { Supported H1 }\end{array}$} \\
\hline $\begin{array}{l}\text { Planning \& control } \\
\text { system }\end{array}$ & $\longrightarrow$ & $\begin{array}{l}\text { Participation } \\
\text { activity }\end{array}$ & & & & & \\
\hline $\begin{array}{c}\text { Planning \& control } \\
\text { system }\end{array}$ & $\longrightarrow$ & $\begin{array}{l}\text { Monitoring } \\
\text { activity }\end{array}$ & 0.525 & 0.061 & 7.080 & $0.000 * *$ & Supported H2 \\
\hline Participation activity & $\longrightarrow$ & $\begin{array}{l}\text { Work safety } \\
\text { performance }\end{array}$ & 0.396 & 0.064 & 6.164 & $0.000 * *$ & Supported H3 \\
\hline Participation activity & $\longrightarrow$ & $\begin{array}{l}\text { Environmental } \\
\text { performance }\end{array}$ & 0.227 & 0.074 & 3.071 & $0.002 *$ & Supported H4 \\
\hline Monitoring activity & $\longrightarrow$ & $\begin{array}{l}\text { Work safety } \\
\text { performance }\end{array}$ & 0.446 & 0.066 & 6.810 & $0.000 * *$ & Supported H5 \\
\hline Monitoring activity & $\longrightarrow$ & $\begin{array}{l}\text { Environmental } \\
\text { performance }\end{array}$ & 0.450 & 0.079 & 5.712 & $0.000 * *$ & Supported H6 \\
\hline
\end{tabular}

\section{Conclusions}

The study results confirmed positive effects of the planning and control system on participation activity (H1) and monitoring activity (H2), and participation activity on work safety performance (H3) and environmental performance (H4). In addition, the study found positive relationships between monitoring activity and work safety performance (H5) and environmental performance (H6).

The main contribution of this research is that it proved that a well-prepared planning and control system can prevent possible risk and improve performance of work safety and work environments. Thus, to ensure sustainable business, organizations should continuously monitor risk, engage in planning and proactive prevention. To engage internal and external employees with suppliers in 
SCM activities, they should be able to first encourage to freely participate and suggest possible solutions to problems. One example of how the planning and control system might be implemented for participation is to understand the key issues of risk and hazards in workplaces [33]. To establish effective collaboration with suppliers, firms should develop long-term strategic relationships with their suppliers for improving competitive advantage, including managing risk for sustainable SCM activities. In addition, firms that are planning to develop a safe workplace should first create environments that allow employees and suppliers to positively participate in devising good solutions to problems. Thus, organizations should invest in sustainable planning and control systems to develop a safe workplace.

Sustainable activities for participation and monitoring should be developed to induce a positive influence on the improvement of work safety and environmental performance. Specifically, these activities can focus on strategies for promoting sustainable activities within SCM including climate change. Based on the results of the study, we assume that a well-developed planning and control system plays a key role in preventing possible risk and improving work safety, which in turn affects organizational performance. Thus, successful safety management requires sustainable activities within SCM.

The results of the study have significant theoretical and practical implications for operational efficiency in SCM. The success and sustainability of firms depend on how effectively they adapt dynamic environment trends, as a diverse group of vendors and stakeholders need to participate in helping remove environmental obstacles. For adapting dynamic environment factors to operational efficiency, effective risk management in SCM is critical [61]. Furthermore, firms should apply different policies and strategies according to workplace conditions and vendor competencies to have effective safety management within SCM because the complexity of the supply chain can create risks at the workplace and human errors [14]. In addition, the improvement of work safety and environmental performance with regard to sustainable commitment may vary based on the type of partnerships established in SCM [1]. Consequently, the results of this study will be guidelines that are provided not only for SCM-related companies, but also for potential firms, who want to establish environment-friendly management environment, and can be applied to find opportunities for enhancing competitiveness in environmental issues in the global market.

This study has some limitations that should be considered when interpreting the findings of this research. First, the data collected and analyzed in this study was from cross industry firms in South Korea. Although South Korea is known as a manufacturing-based country, the motor vehicle sector had the largest proportion of the study sample $(68.0 \%)$, while food and kindred products and the construction industry had a very small sample proportion $(0.5 \%)$. Although the participating firms have similar or different hazards and risks associated with their workplaces, further analysis according to industry types should also be included. Second, this study was conducted only with suppliers. However, comparing suppliers and buyers will provide valuable results for successful safety management and sustainable environment within SCM. If this approach is studied, it can distinguish between first-second tier and second-third tier relationships and understand what options suppliers/vendors actually considered for safety environments through SCM processes.

Conflicts of Interest: The author declares no conflict of interest.

\section{References}

1. Lee, D.; Schniederjans, M. How corporate social responsibility commitment influences sustainable supply chain management performance within the social capital framework: A propositional framework. Int. J. Corp. Strategy Soc. Responsib. 2017, 1, 208-233. [CrossRef]

2. Smith, A. 2017 U.S. billion-dollar weather and climate disasters: A historic year in context. NOAA Climate.gov. 2018. Available online: https:/ / www.climate.gov/news-features/blogs/beyond-data/2017us-billion-dollar-weather-and-climate-disasters-historic-year (accessed on 30 June 2018).

3. Cramer, A.; Park, J.; Olson, E.; Best, B. The Future of Sustainable Business: New Agenda, New Approach, New Advocacy; BSR Report; BSR: New York, NY, USA, 2017. 
4. Kim, M.; Chai, S. Implementing environmental practices for accomplishing sustainable green supply chain management. Sustainability 2017, 9, 1192. [CrossRef]

5. Lee, D. The impact of severe weather and climate change on lean supply chains. J. Korea Ind. Inf. Syst. Res. 2018, 23, 117-129.

6. Occupational Safety and Health Administration (OSHA). Sustainability in the workplace: A new approach for advancing worker safety and health. 2016. Available online: www.osha.gov/sustainability (accessed on 30 June 2018).

7. Duijm, N.; Fiévez, C.; Gerbec, M.; Hauptmanns, U.; Konstandinidou, M. Management of health, safety and environment in process industry. Saf. Sci. 2008, 46, 908-920. [CrossRef]

8. Nordlöf, H.; Wiitavaara, B.; Högberg, H.; Westerling, R. A cross-sectional study of factors influencing occupational health and safety management practices in companies. Saf. Sci. 2017, 95, 92-103. [CrossRef]

9. Occupational Safety and Health (OSH). Act of 1970. Washington. U.S. Congress. Public Law 91-596; Federal Register: Washington, DC, USA, 1970.

10. Swedish Work Environment (SFS). Act: 1160. Swedish Ministry of Employment; Svensk Författningssamling: Stockholm, Sweden, 1977.

11. The Council of the European Communities (EEC). Council Directive of 12 June on the Introduction of Measures to Encourage Improvements in the Safety and Health of Workers at Work; Official Journal of the European Communities No L 183; 89/391/EEC; European Union: Brussels, Belgium, 1989.

12. Barling, J.; Loughlin, C.; Kelloway, E. Development and test of a model linking transformational leadership and occupational safety. J. Appl. Psychol. 2002, 87, 488-496. [CrossRef] [PubMed]

13. Neal, A.; Griffin, M.; Hart, P. The impact of organisational climate on safety climate and individual behaviour. Saf. Sci. 2000, 34, 99-109. [CrossRef]

14. Guiras, Z.; Turki, S.; Rezg, N.; Dolgui, A. Optimal maintenance plan for two-level assembly system and risk study of machine failure. Int. J. Product. Res. 2018, 1-18. [CrossRef]

15. Nordlöf, H.; Wijk, K.; Westergren, K. Perceptions of work environment priorities: Are there any differences by company size? An ecological study. Work J. Prev. Assess. Rehabil. 2015, 52, 697-706. [CrossRef]

16. World Commission on Environment and Development (WCED). Brundtland Report; WCED: Cape Town, South Africa, 1987.

17. Valmohammadi, C. Impact of corporate social responsibility practices on organizational performance: An ISO 26000 perspective. Soc. Responsib. J. 2014, 10, 455-479. [CrossRef]

18. Shrivastava, P. The role of corporations in achieving ecological sustainability. Acad. Manag. Rev. 1995, 20, 936-960. [CrossRef]

19. Góncz, E.; Skirke, U.; Kleizen, H.; Barber, M. Increasing the rate of sustainable change: A call for a redefinition of the concept and the model for its implementation. J. Clean. Product. 2007, 15, 525-537. [CrossRef]

20. Elkington, J. Cannibals with Forks: The Triple Bottom Line of the 21st Century; New Society, Stoney Creek, C.T.: Tauranga, New Zealand, 1998.

21. Carter, C.; Easton, P. Sustainable supply chain management: Evolution and future directions. Int. J. Phys. Distrib. Logist. Manag. 2011, 41, 46-62. [CrossRef]

22. Atkinson, W. Hilton's supply chain ready for anything heading into hurricane season. Purchasing 2006, 135, 24.

23. Carter, C.; Jennings, M. Logistics social responsibility: An integrative framework. J. Bus. Logist. 2002, 23, 145-180. [CrossRef]

24. Klassen, R.; McLaughlin, C. The impact of environmental management on firm performance. Manag. Sci. 1996, 42, 1199-1214. [CrossRef]

25. Hallikas, J.; Karvonen, I.; Pulkkinen, U.; Virolainen, V.; Tuominen, M. Risk management processes in supplier networks. Int. J. Product. Econ. 2004, 90, 47-58. [CrossRef]

26. Carter, C.; Rogers, D. A framework of sustainable supply chain management: Moving toward new theory. Int. J. Phys. Distrib. Logist. Manag. 2008, 38, 360-387. [CrossRef]

27. Reiner, G. Customer-oriented improvement and evaluation of supply chain processes supported by simulation models. Int. J. Product. Econ. 2005, 96, 381-395. [CrossRef]

28. DeJoy, D.; Schaffer, B.; Wilson, M.; Vandenberg, R.; Butts, M. Creating safer workplaces: Assessing the determinants and role of safety climate. J. Saf. Res. 2004, 35, 81-90. [CrossRef] [PubMed]

29. Herrero, S.; Saldaña, M.; del Campo, M.; Ritzel, D. From the traditional concept of safety management to safety integrated with quality. J. Saf. Res. 2002, 33, 1-20. [CrossRef] 
30. Fernández-Muñiz, B.; Montes-Peón, J.; Vázquez-Ordás, C. Safety management system: Development and validation of a multidimensional scale. J. Loss Prev. Process Ind. 2007, 20, 52-68. [CrossRef]

31. Reniers, G.; Dullaert, W.; Ale, B.; Soudan, K. The use of current risk analysis tools evaluated towards preventing external domino accidents. J. Loss Prev. Process Ind. 2005, 18, 119-126. [CrossRef]

32. Flin, R.; Mearns, K.; O'Connor, P.; Bryden, R. Measuring safety climate: Identifying the common features. Saf. Sci. 2000, 34, 177-192. [CrossRef]

33. Oakman, J.; Chan, S. Risk management: Where should we target strategies to reduce work-related musculoskeletal disorders? Saf. Sci. 2015, 73, 99-105. [CrossRef]

34. Petersen, D. Safety management 2000: Our strengths \& weaknesses. Prof. Saf. 2000, 45, 16-19.

35. Santos-Reyes, J.; Beard, A. Assessing safety management systems. J. Loss Prev. Process Ind. 2002, 15, 77-95. [CrossRef]

36. Labodová, A. Implementing integrated management systems using a risk analysis based approach. J. Clean. Product. 2004, 12, 571-580. [CrossRef]

37. Civil Aviation Safety Authority. Safety Management Systems: Getting Started; PMP: Canberra, Australia, 2002.

38. Cialdini, R.B.; Trost, M. Social Influence: Social Norms, Conformity, and Compliance. In The Handbook of Social Psychology; Gilbert, D.T., Fiske, S.T., Gardner, L., Eds.; McGraw-Hill: New York, NY, USA, 1998; pp. 151-192.

39. Mullen, J. Investigating factors that influence individual safety behavior at work. J. Saf. Res. 2004, 35, $275-285$. [CrossRef]

40. Myers, D.; Nyce, J.; Dekker, S. Setting culture apart: Distinguishing culture from behavior and social structure in safety and injury research. Accid. Anal. Prev. 2014, 68, 25-29. [CrossRef]

41. Antonsen, S. Safety culture assessment: A mission impossible? J. Conting. Crisis Manag. 2009, 17, $242-254$. [CrossRef]

42. Choudhry, R.; Fang, D.; Mohamed, S. The nature of safety culture: A survey of the state-of-the-art. Saf. Sci. 2007, 45, 993-1012. [CrossRef]

43. Chardine-Baumann, E.; Botta-Genoulaz, V. A framework for sustainable performance assessment of supply chain management practices. Comput. Ind. Eng. 2014, 76, 138-147. [CrossRef]

44. Attwood, D.; Khan, F.; Veitch, B. Occupational accident models-where have we been and where are we going? J. Loss Prev. Process Ind. 2006, 19, 664-682. [CrossRef]

45. Lingard, H.; Cooke, T.; Blismas, N. Coworkers' response to occupational health and safety: An overlooked dimension of group-level safety climate in the construction industry? Eng. Constr. Archit. Manag. 2011, 18, 159-175. [CrossRef]

46. Neal, A.; Griffin, M. A study of the lagged relationships among safety climate, safety motivation, safety behaviour and accidents at individual and group levels. J. Appl. Psychol. 2006, 91, 946-953. [CrossRef]

47. Green, K.; Zelbst, P.; Meacham, J.; Bhadauria, V. Green supply chain management practices: Impact on performance. Supply Chain Manag. Int. J. 2012, 17, 290-305. [CrossRef]

48. Lee, S.; Lee, D.; Kang, C. The impact of high performance work systems in the health care industry: Employee reactions, service quality, customer satisfaction, and customer loyalty. Serv. Ind. J. 2012, 32, 17-36. [CrossRef]

49. Griffin, M.; Neal, A. Perceptions of safety at work: A framework for linking safety climate to safety performance, knowledge and motivation. J. Occup. Health Psychol. 2000, 5, 347-358. [CrossRef]

50. Zacharatos, A.; Barling, J.; Iverson, R. High-Performance Work Systems and Occupational Safety. J. Appl. Psychol. 2005, 90,77-93. [CrossRef]

51. Hassini, E.; Surti, C.; Searcy, C. A literature review and a case study for sustainable supply chains with a focus on metrics. Int. J. Product. Econ. 2012, 140, 69-82. [CrossRef]

52. Salam, M.; Ali, M.; Kan, S. Focusing on automobile suppliers analyzing supply chain uncertainty to deliver sustainable operational performance: Symmetrical and asymmetrical modeling approaches. Sustainability 2017, 9, 2217. [CrossRef]

53. Chhabara, R. Supply Chain Briefing Part 1: Ethical Sourcing-The Responsible Chain Gang; Ethical Corporation, 2010. Available online: http:/ / www.ethicalcorp.com/supply-chains/supply-chain-briefing-part-1-ethicalsourcing-responsible-chain-gang (accessed on 30 October 2018).

54. Harkness, J. Guidelines for Best Practice in Cross-Cultural Surveys. Survey Research Center; Institute for Social Research: Michigan, MI, USA, 2011.

55. The Global Manufacturing Research Group's (GMRG). Available online: https://gmrg.org/ (accessed on 30 June 2018). 
56. Nunnally, J. Psychometric Theory, 2nd ed.; Mcgraw Hill: New York, NY, USA, 1978.

57. Brown, T.A. Confirmatory Factor Analysis for Applied Research; The Guilford Press: New York, NY, USA, 2006.

58. Deepen, J. Logistics Outsourcing Relationships; Physica-Verlag Heidelberg: New York, NY, USA, 2009.

59. Barclay, D.; Thompson, R.; Higgins, C. The partial least squares (PLS) approach to causal modeling: Personal computer adoption and use as an illustration. Technol. Stud. 1995, 2, 285-309.

60. Fornell, C.; Larcker, D. Evaluating structural equation models with unobservable variables and measurement error. J. Mark. Res. 1981, 18, 39-50. [CrossRef]

61. Tsunemi, K.; Yoshida, K.; Kihara, T.; Saburi, T.; Ono, K. Screening-level risk assessment of a hydrogen refueling station that uses organic hydride. Sustainability 2018, 10, 4477. [CrossRef]

(C) 2018 by the author. Licensee MDPI, Basel, Switzerland. This article is an open access article distributed under the terms and conditions of the Creative Commons Attribution (CC BY) license (http://creativecommons.org/licenses/by/4.0/). 